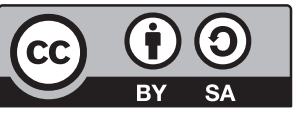

\title{
The Impact of Individual Interest and Proficiency on Self-efficacy Beliefs in Foreign Language Listening
}

\begin{abstract}
Interest and self-efficacy beliefs are important components of motivational constructs that share some common characteristics and influence learning. In this regard, several studies have explored how these two variables relate to each other in various domains and have offered meaningful implications. However, in the field of language learning, it appears that related research is relatively insufficient, and information offered through prior studies is very limited. Therefore, the current study aims to investigate how individual interest in learning English and proficiency influence self-efficacy in listening to expand the current knowledge. With a pre-/post-test design, it analyzed the data collected from 107 EFL Korean university students with a low-intermediate English proficiency, using hierarchical regression analyses. The results reveal that, unlike at the beginning of the course, individual interest turned to be a significant factor in the development of self-efficacy in advanced English listening around the end of the semester, even predicting it more than proficiency did. On the other hand, individual interest influenced self-efficacy in basic English listening much more than proficiency did in the pre-test and maintained this pattern in the post-test. This study provides insightful information into the relationship between interest, self-efficacy, and proficiency, highlighting the essential role of individual interest in learning English. It follows that the maintenance and nurturing of interest is crucial for the development of self-efficacy beliefs which in turn can contribute to advances in language learning.
\end{abstract}

Keywords: individual interest, listening, L2 proficiency, self-efficacy beliefs

Developing listening skills in a foreign language can be a difficult process that may lead students to experience frequent frustrations and negative feelings before attaining a level of satisfactory skill (Graham, 2011). It can be even more challenging for students with low proficiency (Wang \& Fan, 2015). 
Individuals who perceive a given task as difficult, recognize that they do not have the capabilities to perform such a task in a specific field or have repeatedly experienced failure are more likely to have relatively low motivation (Graham, 2007), or may not have much interest in learning a foreign language. Bandura (1997) maintains that an individual's motivation, affective states, and behavior tend to be formed based on their beliefs or self-perceptions rather than on their objective and actual state. This indicates that an individual's positive perceptions such as interest and self-efficacy beliefs are likely to play pivotal roles in academic performance and students may need urgent aid to facilitate them having positive experiences and thus build their positive perception toward language learning.

Interest and self-efficacy are two motivational constructs that come from one's judgments and beliefs accumulated overtime during past learning efforts, which are domain-specific (Hidi et al., 2002). Focusing on the similar characteristics and the influential roles in academic fields that the two variables have in common, a few studies offer some information about the relationship between these two constructs in various educational fields. However, it seems that the details and complexity of these relationships remain relatively little known in language learning circles. The study by Hidi et al. (2002) called for more research on this issue to understand its nature almost two decades ago, yet relevant information on the relationship between them still appears insufficient to result in useful implications. Recognizing the current gap, this study attempts to explore the complexity and interactive characteristics of the two motivational structures, along with the proficiency of Korean university students with a low-intermediate English proficiency level. More specifically, it aims to broaden the scope of information presented by the literature by exploring how students' interest and proficiency influence the formation of self-efficacy in English listening. This may allow us a better understanding of how these motivational variables are related.

\section{Literature Review}

\section{Interest in Language Learning}

Interest in language learning is considered one of the motivational components that help students stay engaged and committed during the learning process (Renniger \& Hidi, 2002). A few researchers claim that interest involves an individual's cognitive and affective aspects (Ainley et al., 2002; Hidi \& Renninger, 2006). More specifically, Hidi and Renninger (2006) claim 
that the positive emotions that accompany engagement can be represented as the affective component of interest, while the perceptual and representational activities in relation to engagement are described as the cognitive counterpart of interest. It appears to be a general consensus that interest may strongly impact the cognitive performance and affective experience of an individual's learning path, leading to positive outcomes (Hidi et al., 2002).

Hidi (1990) differentiates interest into two types: individual interest and situational interest. She defines individual interest as an individual's persistent tendency to repeatedly engage in certain content over time. Since individual interest is related to the previous knowledge and experiences that an individual possesses, it is considered topic-specific and as having more potential for holding personal value for a relatively long period of time. On the other hand, situational interest is defined as the focused attention and affective response initiated while in a particular situation and by stimuli found in the immediate environment and is likely short-lived. This type of interest appears to be context-specific and without long-term value. Previous research indicates that situational interest is likely part of the fundamental constructs of individual interest as suggested in a developmental model of interest (Hidi \& Renninger, 2006; Krapp, 2002; Silvia, 2001).

It should be noted that individual interest appears to have some traits in common with intrinsic motivation, but care should be taken with this interpretation since intrinsic motivation encompasses both individual interest and situational interest (Lee et al., 2014). Individual interest in a specific area is shaped through positive experiences-both in a cognitive and affective manner-during long-term participation in a task or activity related to that specific domain; reflecting a relatively well-developed and sustained form of interest. This serves as a basis for the probability of individual interest working as a concrete construct that can reveal part of an individual's characteristics. For example, a few studies delineate its facilitative role in several fields of learning, such as self-regulation processes and academic performance (Lee et al., 2014; Hidi \& Renninger, 2006; Sansone \& Thoman, 2005; Schiefele et al., 1992). The study by Schiefele et al. (1992) based on meta-analysis shows that individual interest significantly predicts academic achievements, although some differences exist depending on gender. Lee et al. (2014) collected data from 132 Korean adolescents and examined the roles of individual interest in the domains of Korean, English, Mathematics, and Science with other variables using structural equation modeling. The study found remarkably similar patterns in the four subject areas. Individual interest best predicts self-regulation, with self-regulation being the most influential mediator of individual interest and academic performance. These results support the idea that individual interest may also have a relationship with the development of self-efficacy, which is a strong predictor of academic achievement and can be seen to persistently 
help individuals engage with and put effort into their learning processes, in a similar way that interest does (Renninger \& Hidi, 2002).

\section{Self-efficacy Beliefs}

Learning a foreign language involves understanding and becoming familiar with a whole new intricate system of a language - the cultural, social, and linguistic aspects (e.g., syntax, lexis, etc.) of language and language use. In other words, it poses a significant challenge for a student to learn another language that has a completely different system from their mother tongue. In this respect, it is vital for students to have the ability to predict and manage potential challenges or threats appearing in their learning processes, or to have a strong sense of self-efficacy. As individuals exercise their ability to overcome such difficulties as they encounter them, they build a solid sense of efficacy that helps tackle and handle new challenges (Bandura, 1997).

Bandura's (1997) self-efficacy falls within the framework of the social cognitive theory of human functioning that comes from the supposition that humans have the ability to control their behavior, with a self-belief system serving as a possible guide to control what they think, feel, and act. What he defines that as "perceived self-efficacy" refers to beliefs in one's capabilities to organize and execute the course of action required to produce given attainments" (p. 3). In this point of view, a number of scholars maintain that a robust sense of efficacy beliefs equip students with a willingness to face the challenge of given tasks, to make an effort to fulfill them, and to stay on track persistently in order to perform the tasks despite there being obstacles along the way in the learning processes (Bandura, 1997; Kim \& Cha, 2017; Stevens et al., 2004; Vuong et al., 2010).

Not surprisingly, there are a lot of studies that reveal the influential role of self-efficacy in academic achievements or self-regulation, which in turn are related to learning listening skills in language (e.g., Graham, 2007, 2011; Mills et al., 2006; Rahimi \& Abedini, 2009, etc.). The study by Graham (2007, 2011) emphasizes the importance of student self-efficacy in developing listening skills, showing that students benefit from the formation of self-efficacy through listening strategy instruction. Recognizing that selfefficacy is a motivational construct essential for learning, it is very important to look at the relationship of variables that can reinforce students' self-efficacy. 


\section{The Relationship between Interest and Self-efficacy in Learning}

Interest and self-efficacy are reported to have some association with each other in several educational fields such as writing (Hidi et al., 2002), Mathematics (Bandura \& Shunk, 1981), and Physical Education (Zimmerman \& Kitsantas, 1997). Hidi et al. (2002) show that interest and self-efficacy in the same domain or content area can be correlated by sharing the same knowledge base. They contribute to similar behavioral outcomes such as positive emotional reaction, persistence, making an effort, and focused attention during learning processes. This strongly indicates that these two motivational constructs may influence each other's development. However, the nature and method of their interaction still appear to be unclear (Renninger, 2010), and this holds true for the field of L2 learning. It is at this point that the current study finds its relevance and attempts to investigate how these motivational variables are related in the field of L2 listening, which may lead to further consolidate pedagogical and theoretical conjectures. The research questions are as follows.

1. What are the underlying factors found in listening self-efficacy beliefs that beginner to low-intermediate students have?

2. Is there any relationship between interest in learning English, listening proficiency, and self-efficacy beliefs in listening?

3. How do these relationships change over time?

\section{Method}

\section{Participants}

This study was conducted at a university located in eastern Korea, approximately two-hours away from Seoul, by car. This university requires students to take at least two mandatory English courses regardless of major and is offered by the general education center. The 107 participants-who agreed to join the study voluntarily - chose Listening Comprehension (LC), which aims to develop students' listening comprehension skills based on TOEIC.

Most participants' English proficiency varied between beginner and lowintermediate as seen by their TOEIC LC scores taken at the beginning of the course; the average score was $217.3\left(\right.$ S.D. $\left.{ }^{1}=51.0\right)$ out of a total of 495 (see Table 2). Most of them were freshmen from various majors with ages rang-

${ }^{1}$ S.D. $=$ Standard Deviation 
ing from 18 to $24\left(M^{2}=19.2\right.$, S.D. $\left.=1.6\right)$ and had spent an average of about eight years learning English. The 107 students were from the three classes taught by the author. Among them, one class was asked whether they study English apart from in the English class in the third week from the first data collection and 29 participants responded to the question. It was found that only three students (10.3\%) answered that they were studying apart from the English course they were taking and almost $90 \%$ of them $(n=26)$ responded that they got English input only through the English class taught by the author. The data was collected through convenience sampling because the population targeted was considered sufficiently diverse for the aim of the study.

\section{Instruments}

Listening self-efficacy. For this study, eight items of self-efficacy in listening from the English Self-efficacy Questionnaire (Wang et al., 2014) were used. Some of them were modified and some added to suit the educational environment and purpose for which the research was being conducted. Firstly, three original items were modified or eliminated. For example, the item "3. Can you understand American English TV programs?" was modified to "Can you understand English TV programs (e.g., dramas which were produced in the U.S.A, the U.K. or Korea, etc.)?". By deleting the word 'American,' it was intended to expand the concept of English used in many places, not English used only in one region. With this change, item "10. Can you understand English TV programs made in China?" was removed to avoid redundancy. In addition, considering the listening contents covered in class, "15. If your English instructor gives you a tape-recorded English dialogue about everyday school matters, can you understand it?" was changed to "If your English instructor gives you a recorded English dialogue between two or three people, can you understand it?", and then, the following three items were added to measure self-efficacy that can be developed through English listening classes; "Can you concentrate on the content to which you listen?", "Can you understand important information of conversations in English?" "Can you do the tasks and assignments you have to do well, to improve your listening skills?".

In this study, ten items were translated into Korean, considering the level of language proficiency of the participants, and used to measure the participants' self-efficacy beliefs in listening and the overall Cronbach's alpha coefficient was .89 , which is almost the same as that shown in Wang et al.'s $(\alpha=.88)$.

Listening proficiency. The results obtained from the two TOEIC LC tests were used as the participants' listening proficiency data. One of the publishers

${ }^{2} M=$ mean 
that regularly make TOEIC related books provided the tests and they were administered in the first and the twelfth week. The publisher calculated the results. Since the process took about two weeks, the test was taken on the twelfth week so that the students were able to check their grades within the 15 -week course. With a total score of 495 in the listening section, the means of their test results were 217.34 (S.D. $=50.96)$ and $259.35($ S.D. $=65.82)$, respectively.

Interest in English learning (IEL). In this study, IEL represents "individual interest," showing relatively stable affective orientations (Hidi, 1990). In order to elicit the participants' level of individual interest toward learning English, a question, "Do you have interest in learning English?", was asked in a similar way to the study by Hidi et al. (2002). They were instructed to use their own judgment to mark their answer on a six-point Likert scale ranging from 1 and 6 .

\section{Data Collection}

A brief outline of this study was described, and data were collected only from those who agreed to participate. The students were aware that their responses would be released for analysis after the semester is over, and that they would remain anonymous. Data were collected twice in the 15 -week course of the English class; in the second and fourteenth weeks. For the analysis, a dataset of 107 participants who responded to both pre-/post-data collection were used.

\section{Data Analysis}

To address the first research question, an exploratory factor analysis was carried out using the ten-item questionnaire to explore the underlying factors of listening self-efficacy beliefs in the current population. For the second and third research questions, two multiple hierarchical regression analyses were run for each set of pre- and post-tests. The scores of interest and proficiency were used as independent variables and the identified underlying self-efficacy factors were used as dependent variables for analysis.

Hierarchical regression analysis enables examination of whether independent variables significantly predict the identified underlying self-efficacy factors, and further examines which predictors have a greater proportion in explaining the total variance of the dependent variable. In addition, they allow examination of the changes occurring in the patterns of models by comparing the results of pre- and post-tests. 


\section{Results}

To answer research question 1, an exploratory factor analysis was computed, employing the Principal Axis Factoring Extraction method and the Oblique Direct Oblimin Rotation method. Items were eliminated if they were not greater than a cutoff value of 1.0 based on the eigenvalue.

The first trial resulted in a two-factor solution, accounting for $55.1 \%$ of the total variance. All ten items of self-efficacy beliefs in listening yielded a two-factor structure. The six items were loaded on Factor 1 (F1) $(\alpha=.88)$, accounting for $47.5 \%$ of the total variance and was labeled as Self-efficacy in advanced English listening (SAEL) since these items indicate capabilities in advanced levels of listening, such as asking if they can understand mostly authentic texts in English through media such as speeches or TV programs. Factor 2 (F2) included the rest of the four items $(\alpha=.78)$, accounting for $7.6 \%$ of the total variance, and was labeled as Self-efficacy in basic English listening when learning (SBEL). These items are related to activities and tasks required to improve listening competence which are normally conducted during listening classes. A display of the factor loadings gained from factor analysis is shown in Table 1 .

Table 1

Factor loadings for self-efficacy beliefs in listening

\begin{tabular}{|c|c|c|}
\hline \multirow{2}{*}{ SAEL, SBEL } & \multicolumn{2}{|l|}{ Factor } \\
\hline & 1 & 2 \\
\hline \multicolumn{3}{|l|}{ Factor 1: Self-efficacy in advanced English listening (SAEL) } \\
\hline $\begin{array}{l}\text { 2. Can you understand English TV programs (e.g., dramas which were } \\
\text { produced in the U.S.A, the U.K. or Korea, etc.)? }\end{array}$ & 0.853 & \\
\hline 5. Can you understand English movies without subtitles? & 0.848 & \\
\hline $\begin{array}{l}\text { 4. If your English instructor gives you an English dialogue between } \\
\text { two or three people, can you understand it? }\end{array}$ & 0.747 & \\
\hline 3. Can you understand radio programs in English speaking countries? & 0.586 & \\
\hline 6. Can you understand English songs? & 0.582 & \\
\hline 1. Can you understand stories told in English? & 0.567 & \\
\hline \multicolumn{3}{|l|}{ Factor 2: Self-efficacy in basic English listening when learning (SBEL) } \\
\hline 8. Can you concentrate on the content to which you listen? & & 0.745 \\
\hline $\begin{array}{l}\text { 10. Can you do well the tasks and assignments you have to do to } \\
\text { improve your listening skills? }\end{array}$ & & 0.658 \\
\hline 7. Can you understand numbers spoken in English? & & 0.529 \\
\hline $\begin{array}{l}\text { 9. Can you get important information from English conversations heard } \\
\text { in the class? }\end{array}$ & & 0.522 \\
\hline
\end{tabular}

Note. Extraction method: Principal axis factoring / Rotation method: Direct oblimin 
With the second question, this study aimed to uncover any relationship existing between interest in English learning (IEL), listening proficiency, and self-efficacy beliefs in listening when joining the English listening class. Table 2 presents the descriptive statistics for the variables that were collected in pre- and post-data collection. First, when examining the values of the pre-variables, the means for pre-SAEL and pre-SBEL were 2.7 and 3.7, respectively, on a 6-point Likert scale. This may partly reflect the characteristics of the students who have proficiency levels between beginner and intermediate, as evidenced by their listening scores in Table 2. However, their IEL was 4.3 and 4.2; higher than the mid-point.

Table 2

Descriptive statistics for the variables in pre-and post-test

\begin{tabular}{llllll}
\hline Variables & $n$. & Min. & Max. & $M$ & S.D. \\
\hline Pre total self-efficacy & 107 & 1.2 & 4.6 & 3.1 & 0.7 \\
Post total self-efficacy & 107 & 1.3 & 5.3 & 3.5 & 0.8 \\
Pre-SAEL & 107 & 1.0 & 4.3 & 2.7 & 0.8 \\
Pre-SBEL & 107 & 1.5 & 5.3 & 3.7 & 0.8 \\
Post-SAEL & 107 & 1.0 & 5.5 & 3.2 & 0.9 \\
Post-SBEL & 107 & 1.5 & 5.8 & 4.0 & 0.8 \\
Pre-IEL & 107 & 1.0 & 6.0 & 4.3 & 1.3 \\
Post-IEL & 107 & 1.0 & 6.0 & 4.2 & 1.3 \\
$\begin{array}{l}\text { Pre-TOEIC score } \\
\text { (Listening proficiency) }\end{array}$ & 107 & 65.0 & 350.0 & 217.3 & 51.0 \\
Post-TOEIC score & 107 & 130.0 & 460.0 & 259.4 & 65.8 \\
(Listening proficiency) & & & & \\
\hline
\end{tabular}

Note. $n=$ number; $M=$ mean; S.D. = Standard Deviation; SAEL = Self-efficacy in advanced English listening; $\mathrm{SBEL}=$ Self-efficacy in basic English listening when learning; IEL = Interest in English learning

For the pre-test, the relationship between IEL, listening proficiency, and self-efficacy beliefs in listening when joining the English listening class was explored. Hierarchical multiple regression was employed for the analyses. The dependent variable was SAEL and the independent variables were IEL and listening proficiency. As Model 1 shows in Table 3, when IEL alone was used as an independent variable, it significantly predicted SAEL, $F(1,105)=7.89$, $p=.01$, accounting for $7 \%$ of the total variance $(R=.26)$. However, when proficiency was put along with IEL as independent variables, IEL failed to retain its significance as a variable that influences SAEL $(p=.11)$. In other words, while Model 2 was significant, $F(2,104)=9.88, p=.001$, accounting for $16 \%$ of the total variance, proficiency was the only variable that significantly predicts SAEL $(p=.001)$. The summary of Table 3 is illustrated in Figure 1. 
Table 3

The regression models with SAEL as a dependent variable for pre-test

\begin{tabular}{|c|c|c|c|c|c|c|c|}
\hline \multicolumn{2}{|c|}{ Independent variable(s) } & \multicolumn{2}{|c|}{$\begin{array}{l}\text { Unstandardized } \\
\text { Coefficients }\end{array}$} & \multirow{2}{*}{$\begin{array}{l}\text { Standardized } \\
\text { Coefficients } \\
\text { beta }\end{array}$} & \multirow[b]{2}{*}{$t$-value } & \multirow[b]{2}{*}{$p$-value } & \multirow[b]{2}{*}{$R^{2}$} \\
\hline & & $B$ & $S E$ & & & & \\
\hline \multirow{2}{*}{ Model 1} & (Constant) & 1.98 & .26 & & 7.61 & .00 & .07 \\
\hline & Pre-IEL & .16 & .06 & .26 & 2.81 & .01 & \\
\hline \multirow{3}{*}{ Model 2} & (Constant) & 1.21 & .34 & & 3.55 & .00 & .16 \\
\hline & Pre-IEL & .10 & .06 & .16 & 1.63 & .11 & \\
\hline & $\begin{array}{l}\text { Pre-listening } \\
\text { proficiency }\end{array}$ & .00 & .00 & .32 & 3.33 & .00 & \\
\hline
\end{tabular}

Note. SAEL $=$ Self-efficacy in advanced English listening; IEL = Interest in English learning

\begin{tabular}{|c|c|c|c|}
\hline \multirow{2}{*}{ Model 1} & \multirow{2}{*}{$\begin{array}{l}\text { Interest in English } \\
\text { learning (IEL) }\end{array}$} & $.26 * *$ & \multirow{2}{*}{$\begin{array}{l}\text { Self-efficacy in advanced } \\
\text { English listening (SAEL) }\end{array}$} \\
\hline & & & \\
\hline
\end{tabular}

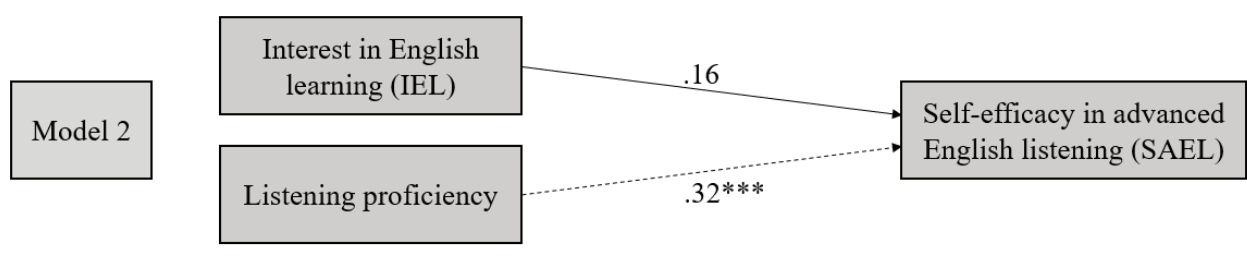

$* p<.05, * * p<.01, * * * p<.001$

Figure 1. The relationship between the variables and SAEL for pre-test

Another hierarchical regression was conducted to examine how interest and proficiency affect SBEL for the pre-test. SBEL was used as the dependent variable and IEL and listening proficiency were the independent variables. As Model 3 shows in Table 4, when IEL alone was used as an independent variable, it significantly predicted SBEL, $F(1,105)=55.28$, $p=.001$, accounting for $35 \%$ of the total variance $(R=.59)$. When proficiency was put along with IEL as the independent variables in Model 4 , this model was found to be significant, $F(2,104)=33.42, p=.001$, accounting for $39 \%$ of the total variance, predicting $4 \%$ more than that of Model 3 . Examining the two predictor variables, IEL predicted SBEL far more strongly (beta $=.51)$ than proficiency (beta $=.23$ ). The summary of Table 4 is illustrated in Figure 2. 
Table 4

The regression models with SBEL as a dependent variable for pre-test

\begin{tabular}{|c|c|c|c|c|c|c|c|}
\hline \multirow{2}{*}{\multicolumn{2}{|c|}{ Independent variable(s) }} & \multicolumn{2}{|c|}{$\begin{array}{l}\text { Unstandardized } \\
\text { Coefficients }\end{array}$} & \multirow{2}{*}{$\begin{array}{l}\text { Standardized } \\
\text { Coefficients } \\
\text { beta }\end{array}$} & \multirow[b]{2}{*}{$t$-value } & \multirow[b]{2}{*}{$p$-value } & \multirow[b]{2}{*}{$R 2$} \\
\hline & & $B$ & SE & & & & \\
\hline \multirow{2}{*}{ Model 3} & (Constant) & 2.18 & .21 & & 10.30 & .00 & .35 \\
\hline & Pre-IEL & .35 & .05 & .59 & 7.44 & .00 & \\
\hline \multirow{3}{*}{ Model 4} & (Constant) & 1.64 & .28 & & 5.85 & .00 & .39 \\
\hline & Pre-IEL & .30 & .05 & .51 & 6.26 & .00 & \\
\hline & $\begin{array}{l}\text { Pre-listening } \\
\text { proficiency }\end{array}$ & .00 & .00 & .23 & 2.81 & .01 & \\
\hline
\end{tabular}

Note. SBEL = self-efficacy in basic English listening when learning; IEL = Interest in English learning

\begin{tabular}{|c|c|c|c|}
\hline \multirow{2}{*}{ Model 3} & \multirow{2}{*}{$\begin{array}{l}\text { Interest in English } \\
\text { learning (IEL) }\end{array}$} & \multirow[t]{2}{*}{$.59 * * *$} & Self-efficacy in basic English \\
\hline & & & listening when learning (SBEL) \\
\hline
\end{tabular}

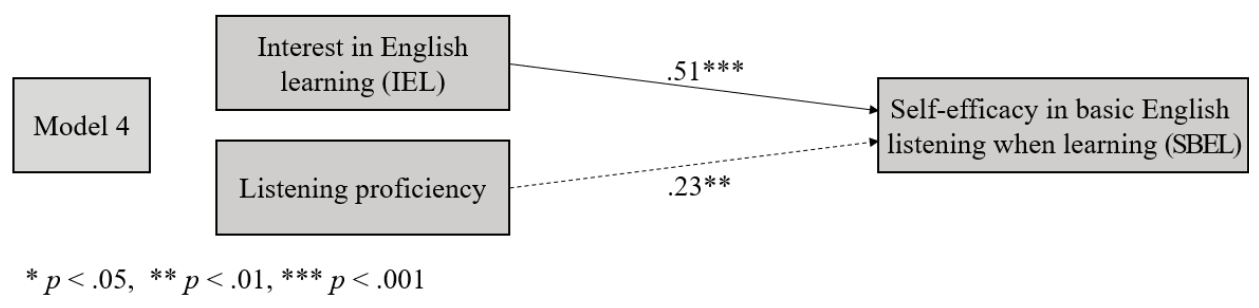

Figure 2. The relationship between the variables and SBEL for pre-test

The third research question was related to the changes in the relationship between the variables on each self-efficacy in listening over time. In the post-test, the results of the hierarchical multiple regression indicate that the explanatory values of the two predictor variables-IEL and proficiency on SAEL increased considerably, compared to those of the pre-test. For example, Model 5 with IEL as a single independent variable was significant, $F(1,105)=26.73, p=.001$, accounting for $20 \%$ of the total variance $(R=.45), 13 \%$ more than that of the pre-test. Model 6 with both IEL and proficiency as independent variables was also found significant, $F(2,104)=16.13, p=.001$, accounting for $24 \%$ of total variance which is $8 \%$ more than that of the pre-test. It is worth noting that among the two variables, IEL was still a significant variable when proficiency was put as a combined variable on SAEL, a result different from the pre-testthe contribution of IEL to SAEL became insignificant when proficiency was 
put in as a combined independent variable (see Table 3). Moreover, IEL had more predictor value (beta $=.38)$ than that of proficiency $($ beta $=.20)$ on SAEL this time. In other words, the contribution of IEL became almost twice as high as that of proficiency after a series of lessons aimed at learning to listen. The summary of Table 5 is illustrated in Figure 3.

Table 5

The regression models with SAEL as a dependent variable for post-test

\begin{tabular}{|c|c|c|c|c|c|c|c|}
\hline \multicolumn{2}{|c|}{ Independent variable(s) } & \multicolumn{2}{|c|}{$\begin{array}{l}\text { Unstandardized } \\
\text { Coefficients }\end{array}$} & \multirow{2}{*}{$\begin{array}{l}\text { Standardized } \\
\text { Coefficients } \\
\text { beta }\end{array}$} & \multirow[b]{2}{*}{$t$-value } & \multirow[b]{2}{*}{$p$-value } & \multirow[b]{2}{*}{$R 2$} \\
\hline & & $B$ & $S E$ & & & & \\
\hline \multirow{2}{*}{ Model 5} & (Constant) & 1.90 & .26 & & 7.19 & .00 & .2 \\
\hline & Post-IEL & .31 & .06 & .45 & 5.17 & .00 & \\
\hline \multirow{3}{*}{ Model 6} & (Constant) & 1.43 & .34 & & 4.26 & .00 & .24 \\
\hline & Post-IEL & .26 & .06 & .38 & 4.05 & .00 & \\
\hline & $\begin{array}{l}\text { Post- } \\
\text { listening } \\
\text { proficiency }\end{array}$ & .00 & .00 & .20 & 2.15 & .03 & \\
\hline
\end{tabular}

Note. SAEL = Self-efficacy in advanced English listening; IEL = Interest in English learni

\begin{tabular}{|c|c|c|c|}
\hline $\begin{array}{c}\text { Interest in English } \\
\text { learning (IEL) }\end{array}$ & $.45^{* * *}$ & $\begin{array}{l}\text { Self-efficacy in advanced } \\
\text { English listening (SAEL) }\end{array}$
\end{tabular}

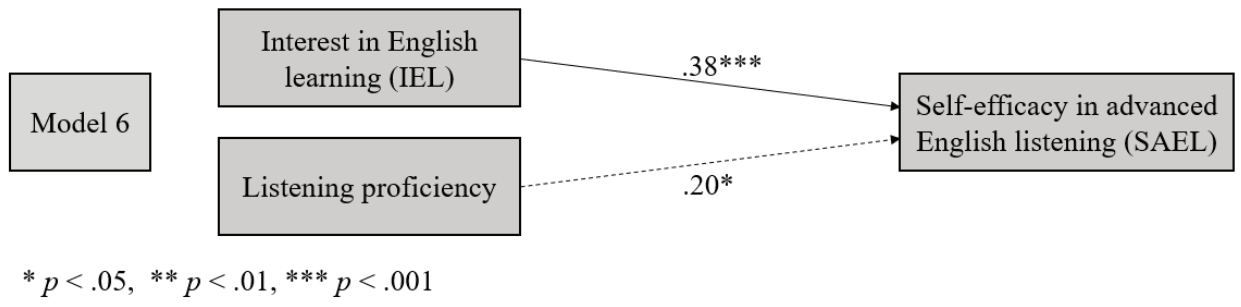

Figure 3. The relationship between the variables and SAEL for post-test

To investigate the impact of the two variables on SBEL in the post-test, a hierarchical multiple regression was performed. When IEL was put in as a single independent variable, its contribution to SBEL was significant, $F(1,105)=45.12, p=.001$, accounting for $30 \%$ of the total variance. When proficiency was combined along with IEL, these two predictor variables significantly affected SBEL, $F(2,104)=26.81, p=.001$, accounting for $34 \%$ of the total variance. Compared to the results of the pre-test, the predicting values of the independent variables decreased moderately. However, these 
values remained in a similar pattern. In other words, IEL had a better explanatory value-more than double-with SBEL than proficiency did in both the pre- and post-test (see Figure 2 and 4). This illustrates that SBEL increases as both IEL and proficiency increase, but the degree of IEL has more influence on SBEL than proficiency.

Table 6

The regression models with SBEL as a dependent variable for post-test

\begin{tabular}{|c|c|c|c|c|c|c|c|}
\hline \multicolumn{2}{|c|}{ Independent variable(s) } & \multicolumn{2}{|c|}{$\begin{array}{l}\text { Unstandardized } \\
\text { Coefficients }\end{array}$} & \multirow{2}{*}{$\begin{array}{l}\text { Standardized } \\
\text { Coefficients } \\
\text { beta }\end{array}$} & \multirow[b]{2}{*}{$t$-value } & \multirow[b]{2}{*}{$p$-value } & \multirow[b]{2}{*}{$R 2$} \\
\hline & & $B$ & $S E$ & & & & \\
\hline \multirow{2}{*}{ Model 7} & (Constant) & 2.52 & .23 & & 11.01 & .00 & .3 \\
\hline & Post-Interests & .35 & .05 & .55 & 6.72 & .00 & \\
\hline \multirow{3}{*}{ Model 8} & (Constant) & 2.06 & .29 & & 7.10 & .00 & .34 \\
\hline & Post-Interests & .30 & .06 & .47 & 5.42 & .00 & \\
\hline & $\begin{array}{l}\text { Post-listening } \\
\text { proficiency }\end{array}$ & .00 & .00 & .22 & 2.50 & .01 & \\
\hline
\end{tabular}

Note. SBEL = self-efficacy in basic listening when learning; IEL = Interest in English learning

\begin{tabular}{|c|c|c|}
\hline $\begin{array}{c}\text { Interest in English } \\
\text { learning (IEL) }\end{array}$ & $.55^{* * *}$ & $\begin{array}{c}\text { Self-efficacy in basic English } \\
\text { listening when learning (SBEL) }\end{array}$ \\
\hline
\end{tabular}

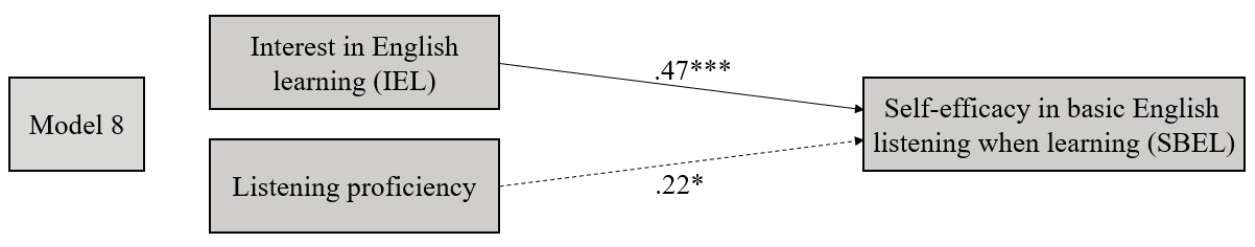

$* p<.05, * * p<.01, * * * p<.001$

Figure 4. The relationship between the variables and SBEL for post-test

\section{Discussion}

This study aimed to examine the effects of IEL — individual interest — and proficiency on self-efficacy beliefs which are considered an important contributor to an individual's academic development in the domain of listening. As 
shown by the average scores of the two TOEIC LC tests, most of the participants consisted of EFL university students who have an English proficiency ranging from beginner to low-intermediate. Notably, the scores of self-efficacy and listening performances increased by the end of the course as compared to those collected at the beginning of the course as shown in the descriptive statistics, but the IEL scores remained almost intact. This partly reflects the nature of individual interest in that it is considered to possess more potential for holding personal value for a relatively long period of time without much change (Hidi, 1990; Hidi \& Harackiewicz, 2000).

When participants began taking this course, IEL as a single independent variable maintained its significance in predicting SAEL, but it is worth noting that its significance was lost when placed together with listening proficiency as another independent variable. In other words, the interest of participants with low proficiency in English did not play a role in predicting self-efficacy in performing advanced listening skills, mostly dealing with authentic texts, when considered alongside listening proficiency. This may be due to the possibility that engaging in difficult listening activities can be considered a daunting task for these participants to approach, even armed with their interest in learning English.

Conversely, it is considered a natural result to discover that listening proficiency is a predictor for self-efficacy beliefs especially in dealing with highlevel listening tasks since several studies support the close relationship between them (e.g., Bong \& Skaalvik, 2003; Cubillos \& Ilvento, 2013; Graham, 2011; Mills et al., 2006, etc.)

Around the end of the course, however, the data analysis results show a markedly different pattern in the relationship between IEL and SAEL from those of the pre-test (see Table 3 and 5). For example, IEL as a single independent variable plays a significant role in predicting the formation of SAEL and explains SAEL approximately three times (20\%) more in the post-test (Model 5) than the model in the pre-test (Model 1). Moreover, even when English proficiency is put as a predictor along with IEL, IEL does not lose its significance and rather is shown to have more (about twice as much) influence on SAEL than English proficiency (Model 6). This means that interest did not play a role in predicting the development of SAEL in the beginning, but over time, interest turned into an influential variable, even more influential than English proficiency.

Although they had a relatively high level of interest, the pre-test result suggests that students with low proficiency in English did not describe themselves as capable of advanced listening skills. It is likely that such a result may have been caused by them cognitively recognizing the gap between their skills, based on their subjective judgments, and the level of English listening activities they knew they would face at the beginning of the course or the authentic materials they would have to listen to. The post-test result, however, indicates that the interest they possess in learning English may emerge as a significant 
and influential facilitator of their efficacy beliefs in listening to and understanding difficult or authentic materials through a series of learnings such as taking classes, even for students who are considered low-intermediate. It is worth recalling that at the time of data collection, few students were learning English other than in the English course, despite the data being collected from only one of the three classes (see Participant section in Method). This possibly indicates that the majority of their input of English learning was through the English course that they were taking. It is plausible to infer that the four major sources of self-efficacy that Bandura (1997) indicates-personal success in performing listening activities (mastery experiences), observed indirect successful experiences by classmates (vicarious experiences), received encouragements and positive feedback from the teacher and classmates (social persuasion), and psychological and affective states (Bandura, 1997) - may have contributed to such a pattern of changes. However, such casual relationships could not be investigated further as they fall beyond the scope of the current study. The positive experiences students likely have through the classes can turn students' interest into a factor that actually affects self-efficacy.

Regarding the SBEL, at the beginning of the course, the participants who had interest in studying English seem to have the idea that they are capable of performing listening activities that require the basic skills needed to improve listening competence, which are normally conducted during listening classes (e.g., understanding numbers spoken in English, concentrating on listening content, performing related activities, etc.). This is seen in Models 3 and 4, accounting for $35 \%$ and $39 \%$ of total variance respectively and IEL had a greater effect on SBEL than actual English proficiency, unlike its effect on SAEL. This indicates that these participants' perception that they are interested in English learning affects their self-efficacy making them believe that they can perform listening activities at a relatively easy level. Even around the end of the semester, this pattern remained unchanged; although interest had a higher influence on SBEL in both models (models 4 and 8), the explanatory powers of the two post-models (Model 7 and 8) became moderately smaller than those of the pre-test, decreasing by $5 \%$ of the total variance each. This is possible because as time went by, most students seem to perceive that they have obtained the enhanced ability to deal with and get used to handling a basic level of activities with relative ease, through participation in the classes. In this respect, it can be inferred that the explanatory powers in the regression models decreased moderately in the post-test whereas the regression models maintained the same pattern-individual interest has a greater influence on the development of SBEL - in both pre- and post-test. Looking at the relationship between IEL and SBEL in pre- and post-results indicates that providing only an appropriate level of activities that are not demanding or challenging for the student's level does not help develop self-efficacy. 


\section{Conclusion}

This study aimed to understand the complexities and the nature of interest and self-efficacy beliefs in university students with low English proficiency in Korea. The findings show that their interest in English learning was quite high despite the participants of this study having had little success in learning English in a relatively long period of time. In addition, these students were found to have their self-efficacy in a provisional or malleable state (Klassen, 2006) - a transitional state of self-efficacy that is still undergoing changes and has positive development even in students with a low level of proficiency. Moreover, it was revealed that the formation of self-efficacy beliefs in performing advanced listening skills can be facilitated by individual interest, one of the motivational variables in learning English. As Hidi and Harackiewicz (2000) highlight, students' interest is likely to influence the development of a strong sense of efficacy over time since interest plays a strong facilitating role in cognitive function. In this respect, helping students develop their interest in language learning is effective in developing their self-efficacy beliefs.

Individual interest and self-efficacy beliefs are particularly important in that they are motivational constructs that can influence learning processes. The findings of this study suggest that even for those with a low-proficiency and relatively little success in learning EFL, it is important to ensure the continuation of individual interest in English learning. If done correctly, the possibility of the student's progress is substantially higher than if their interests are not taken into account. When individual interest in one domain is met with several conducive learning conditions, it may play a role as a facilitator of self-efficacy. It would be worth investigating what role individual interest plays as a mediator in the formation of self-efficacy beliefs in future studies. Notably, the results were derived from convenience sampling and cannot be generalized. This suggests further research is needed with different samples. In addition, a valid and reliable instrument to measure individual interest should be considered to better support the findings.

\section{References}

Ainley, M., Hidi, S., \& Berndorff, D. (2002). Interest, learning, and the psychological processes that mediate their relationship. Journal of Educational Psychology, 94(3), 545-561.

Bandura, A. (1997). Self-efficacy: The exercise of control. W. H. Freeman and Company.

Bandura. A., \& Schunk, D. H. (1981). Cultivating competence, self-efficacy, and intrinsic interest through proximal self-motivation. Journal of Personality and Social Psychology, 41(3), 586-598. 
Bong., M., \& Skaalvik, E. M. (2003). Academic self-concept and self-efficacy: How different are they really? Educational Psychology Review, 15(1), 1-40.

Cubillos, J. H., \& Ilvento, T. (2013). The impact of study abroad on students' self-efficacy perceptions. Foreign Language Annals, 45(4), 494-511.

Graham, S. (2007). Learner strategies and self-efficacy: Making the connection. Language Learning Journal, 35(1), 81-93.

Graham, S. (2011). Self-efficacy and academic listening. Journal of English for Academic Purposes, 10(2), 113-117.

Hidi, S. (1990). Interest and its contribution as a mental resource for learning. Review of Educational Research, 60(4), 549-571.

Hidi, S., Berndorff, D., \& Ainley, M. (2002). Children's argument writing, interest and self-efficacy: An intervention study. Learning and Instruction, 12(4), 429-446.

Hidi, S., \& Harackiewicz, J. (2000). Motivating the academically unmotivated: A critical issue for the 21st century. Review of Educational Research, 70(2), 151-179.

Hidi, S., \& Renninger, K. A. (2006). The four-phase model of interest development. Educational Psychologist, 41(2), 111-127.

Kim, H. I., \& Cha, K. A. (2017). Effects of experience abroad and language proficiency on self-efficacy beliefs in language learning. Psychological Reports, 120(4), 670-694.

Klassen, R. M. (2006). Too much confidence: The self-efficacy of adolescents with learning disabilities. In F. Pajares \& T. Urdan (Eds.), Self-efficacy beliefs of adolescents (pp. 181-200). Information Aga Publishing.

Krapp, A. (2002). Structural and dynamic aspects of interest development: Theoretical considerations from an ontogenetic perspective. Learning and Instruction, 12(4), 383-409.

Lee, W., Lee, M., \& Bong, M. (2014). Testing interest and self-efficacy as predictors of academic self-regulation and achievement. Contemporary Educational Psychology, 39(2), 86-99.

MacIntyre, P. D., \& Mercer, S. (2014). Introducing positive psychology in SLA. Studies in Second Language Learning and Teaching, 4(2), 153-172.

Mills, N., Pajares, F., \& Herron, C. (2006). A reevaluation of the role of anxiety: Self-efficacy, anxiety, and their relation to reading and listening proficiency. Foreign Language Annals, 39(2), 276-295.

Rahimi, A., \& Abedini, A. (2009). The interface between EFL learners' self-efficacy concerning listening comprehension and listening proficiency. Novitas-ROYAL (Research on Youth and Language), 3(1), 14-28.

Renninger, K. A., \& Hidi, S. (2002). Student interest and achievement: Developmental issues raised by a case study. In A. Wigfield \& J. S. Eccles (Eds.), Development of achievement motivation (pp. 173-195). Academic.

Renninger, K. A. (2010). Working with and cultivating the development of interest, self-efficacy, and self-regulation. In D. D. Preiss \& R. J. Sternberg (Eds.), Innovations in educational psychology: Perspectives on learning, teaching, and human development (pp. 107-138). Springer Publishing Company.

Sansone, C., \& Thoman, D. B. (2005). Interest as the missing motivator in self-regulation. European Psychologist, 10(3), 175-186.

Schiefele, U., Krapp, A., \& Winteler, A. (1992). Interest as a predictor of academic achievement: A meta-analysis of research. In K. A. Renninger, S. Hidi, \& A. Krapp (Eds.), The role of interest in learning and development (pp. 183-212). Erlbaum.

Silvia, P. J. (2001). Interest and interests: The psychology of constructive capriciousness. Review of General Psychology, 5(3), 270-290. 
Stevens, T., Olivarez, A. Lan, W. Y., \& Tallent-Runnels, M. K. (2004). Role of mathematics self-efficacy and motivation in mathematics performance across ethnicity. The Journal of Educational Research, 97(4), 208-221.

Vuong, M., Brown-Welty, S., \& Tracz, S. (2010). The effects of self-efficacy on academic success of first-generation college sophomore students. Journal of College Student Development, 51(1), 50-64.

Wang, L., \& Fan, J. (2015). Listening difficulties of low-proficiency EFL learners: A comparison of teacher and learner perspectives. The Asian EFL Journal, 17(3), 85-110.

Wang, C., Kim, D. H., Bai, R., \& Hu, J. (2014). Psychometric properties of a self-efficacy scale for English language learners in China. System, 44(1), 24-33.

Zimmerman, B. J., \& Kitsantas, A. (1997). Developmental phases in self-regulation: Shifting from progress to outcome goals. Journal of Educational Psychology, 89(1), 29-36.

Hyang-Il Kim

\section{Der Einfluss von individuellen Interessen und Kenntnissen auf Selbstwirksamkeitsüberzeugungen im Verstehen von Fremdsprachen}

\section{Zusammenfassung}

Interesse und Selbstwirksamkeitsüberzeugungen sind wichtige Bestandteile von Motivationskonstrukten, die einige gemeinsame Merkmale aufweisen und einen Einfluss auf den Lernprozess haben. In diesem Zusammenhang hat man in mehreren Studien untersucht, wie die beiden Variablen unter verschiedenen Aspekten miteinander in Beziehung stehen, und auf dieser Grundlage sinnvolle Schlussfolgerungen formuliert. Nichtsdestotrotz scheint die diesbezügliche Forschung im Bereich des Fremdsprachenlernens relativ unzureichend und die aus den früheren Studien gewonnenen Informationen sehr begrenzt zu sein. Aus diesem Grund ist die vorliegende Studie darauf abgezielt, zu untersuchen, wie das individuelle Interesse am Englischlernen und Sprachkenntnisse die Selbstwirksamkeit im Hörverstehen beeinflussen, um das vorhandene Wissen zu erweitern. Mittles eines Vortest-NachtestDesigns wurden die Daten von 107 koreanischen EFL-Studenten mit niedrigeren mittleren Englischkenntnissen unter Verwendung hierarchischer Regressionsanalysen ausgewertet. Die Ergebnisse zeigen, dass, anders als zu Beginn des Kurses, das individuelle Interesse ein signifikanter Faktor bei der Entwicklung von Selbstwirksamkeit in Bezug auf die fortgeschrittene Kompetenz am Ende des Semesters war und sie sogar mehr voraussagte als Sprachkenntnisse. Von der anderen Seite hatte das individuelle Interesse einen viel stärkeren Einfluss auf die grundsätzliche Selbstwirksamkeit im Hörverstehen als die Sprachkenntnisse im Vortest und dieses Modell wurde auch im Nachtest beibehalten. Die Studie bietet auch aufschlussreiche Informationen über die Wechselbeziehung zwischen Interesse, Selbstwirksamkeit bzw. Leistung und hebt die bedeutende Rolle des individuellen Interesses beim Englischlernen hervor. Daraus folgt, dass die Aufrechterhaltung und Förderung des Interesses entscheidend für die Entwicklung von Selbstwirksamkeitsüberzeugungen ist, die wiederum zu Fortschritten beim Fremdsprachenlernen beitragen können.

Schlüsselwörter: individuelles Interesse, Hörverstehen, Fremdsprachenkenntnisse, Selbstwirksamkeitsüberzeugungen 